\title{
Uma análise da releitura coreográfica de Erosão, composição de Heitor Villa-Lobos, por Luiz Bongiovanni
}

\author{
Charlotte Riom \\ Fundação Getúlio Vargas, Rio de Janeiro \\ Universidade Paris-Sorbonne \\ charlotteriom@gmail.com \\ https://orcid.org/0000-0001-6320-7330
}

\begin{abstract}
Resumo: $\mathrm{O}$ intuito desse artigo é apresentar uma análise da interpretação da coreografia de Erosão, composição criada por Heitor Villa-Lobos, executada pelo paulista Luiz Bongiovanni. Composta em 1950, Erosão é o segundo balé sobre música de Villa-Lobos que faz parte da Trilogia Amazônica, um conjunto de três coreografias - Uirapuru, Erosão e Alvorecer - sobre composições do compositor brasileiro que foi encomendado pelo Maestro André Cardoso, em 2015, para o Theatro Municipal do Rio de Janeiro. Esta foi apresentada nos meses de julho e agosto de 2016, durante as Olimpíadas, e teve como mote os temas relacionados à ecologia e à natureza. Examinaremos, em primeiro lugar, a contribuição de Villa-Lobos para a dança e o balé, focando em particular nos gêneros do poema sinfônico e do balé que definem Erosão. Em seguida, apresentaremos uma análise da releitura da obra musical pela coreografia contemporânea de Luiz Bongiovanni.
\end{abstract}

Palavras-chave: Música, Dança contemporânea, Dramaturgia, Interpretação cênica.

\section{An analysis of the choreographic interpretation of Erosion, music composed by Heitor Villa-Lobos and choreographed by Luiz Bongiovanni}

\begin{abstract}
The purpose of this article is to present an analysis of the choreographic interpretation of Erosion, composed by Heitor Villa-Lobos and choreographed by the paulista choreographer, Luiz Bongiovanni. Composed in 1950, Erosion is the second work about Villa-Lobos music, forming the Amazon Trilogy, a set of three choreographies - Uirapuru, Erosão and Alvorecer - about compositions by the Brazilian composer that was commissioned, in 2015, by the Maestro André Cardoso for the Municipal Theater of Rio de Janeiro. This was presented in July and August of 2016, during the Olympics, and had as its themes, ecology and nature. We will first examine Villa-Lobos' contribution to dance and ballet, focusing particularly on the genres of symphonic poem and ballet that define Erosion. Then, we will present an analysis of the interpretation of the musical work by the contemporary choreography of Luiz Bongiovanni.
\end{abstract}

Keywords: Music, Contemporary Dance, Dramaturgy, Scenic interpretation.

\section{Un análisis de la interpretación coreográfica de Erosión, composición de Heitor Villa-Lobos, de Luiz Bongiovanni}

Resumen: El propósito de este artículo es presentar un análisis de la interpretación de la coreografía de Erosion, composición creada por Heitor Villa-Lobos y interpretada por Luiz Bongiovanni, de São Paulo. Compuesto en 1950, Erosion es el segundo ballet sobre música de Villa-Lobos y forma parte de la Trilogía del Amazonas, un conjunto de tres coreografías - Uirapuru, Erosão y Alvorecer - sobre composiciones del compositor brasileño, que fue encargada, en 2015, por el Maestro André Cardoso para el Teatro Municipal de Río de Janeiro. Esto se presentó en los meses de julio y agosto de 2016, durante los Juegos Olímpicos, y tuvo como temas relacionados la ecología y la naturaleza. Primero, examinaremos la contribución de Villa-Lobos a la danza y el ballet, centrándonos en particular en los géneros de poema sinfónico y ballet que definen Erosion. Luego, presentaremos un análisis de la interpretación de la obra musical de la coreografía contemporánea de Luiz Bongiovanni.

Palabras-clave: Música, Danza contemporánea, Dramaturgia, Interpretación escénica. 


\section{Introdução}

Erosão é o segundo balé da Trilogia Amazônica, um conjunto de três coreografias - Uirapuru, Erosão e Alvorecer - sobre composições de Villa-Lobos encomendado pelo Maestro André Cardoso para o Teatro Municipal do Rio de Janeiro, então dirigido pelo compositor João Guilherme Ripper, na ocasião da primeira edição dos Jogos Olímpicos na América Latina. Esta trilogia foi apresentada nos meses de julho e agosto de 2016 durante esse evento esportivo internacional e teve como mote os temas relacionados à ecologia e à natureza, focalizando em sua força e em sua destruição, pelo ser humano. A coreografia de Erosão foi realizada sobre o poema sinfônico do mesmo nome de VillaLobos, composto em 1950. Assim, em um momento em que o Brasil se tornava centro das atenções em um plano mundial, a figura de Villa-Lobos representaria o elemento central de uma criação de caráter nacional, por ser “indubitavelmente o mais 'oficial' de todos os músicos brasileiros" (AZEVEDO, 2016, p. 222) - ademais de seu reconhecimento internacional. O compositor foi escolhido, portanto, como representante da cultura brasileira. A Trilogia Amazônica é o resultado da reunião de três coreógrafos brasileiros que atuam ou atuaram fora do Brasil e do Rio de Janeiro, incluindo o coreógrafo paulista Luiz Fernando Bongiovanni Martins (São Paulo, 1970-), que assumiu a primeira coreografia de Erosão.

Obra composta para dezoito dançarinos e com duração de aproximadamente vinte minutos, a coreografia de Erosão corresponde a um estilo contemporâneo de dança. A cenografia foi criada pelo arquiteto e cenógrafo carioca Gringo Cardia, colaborador da coreógrafa carioca Deborah Colker desde 1994. A responsabilidade pela iluminação fícou com Maneco Quinderé e o figurino com René Salazar. Por fim, a regência esteve a cargo do Maestro Tobias Volkmann, à frente da Orquestra Sinfônica do Theatro Municipal de Rio de Janeiro.

Apesar de pouca conhecida, a contribuição de Villa-Lobos para a dança e para o balé é significativa, tendo sido marcada, de um lado, por preocupações modernistas, incorporação do folclore e da natureza, encontros com personalidades famosas, e de outro, por projetos infrutíferos. Todavia, no que tange às suas experiências com a dança, Villa-Lobos desenvolveu uma compreensão do balé de acordo com a estética musical e coreográfica de sua época, faceta até hoje pouco explorada por pesquisadores de sua obra. 
Assim, a declaração do compositor a respeito da composição do seu balé Rudá (Dio d'Amore), em 1951: "Aqui temos a dança pela dança [...]" (MARIZ, 1989, p. 155), demonstra, de um lado, uma influência da música sobre a dança, que se vê integrada nesta, pensada como ferramenta composicional - procedimento que lembra o de Igor Stravinsky (1882-1971) -, e de outro, a vontade de não ficar restrito às narrativas e leitmotiven rítmicos, herdeiros do balé romântico e ainda presentes em alguns balés de Diaghilev, cuja companhia de dança era conhecida no Brasil desde o início do século XX.

Devido a duas temporadas na América Latina, em 1913 e em 1917, e pela contribuição de alguns dos seus dançarinos, a Companhia dos Balés Russos teve, com efeito, um impacto na formação do balé no Brasil. Após o falecimento de Sergei Diaghilev, em 1929, que marcou também o fim das atividades dessa agremiação, alguns dos seus dançarinos criaram suas próprias companhias de balé por todo o Ocidente, como a dançarina Ana Pavlova. No Rio de Janeiro, ela formou Maria Olenewa, que criou, em 1927, a Escola Estadual de Dança do Theatro Municipal do Rio de Janeiro, formando pioneiramente um corpo de baile no país. Dançarinos imigrantes russos, instalados por questões políticas na então capital do Brasil, participaram, com o recém formado corpo de baile do Theatro, da criação de balés com temas nacionais, na linha dos de Diaghilev. Este introduziu o estilo neoclássico - que contribuiu para o enriquecimento da técnica clássica e de sua renovação ao libertar certos movimentos -, que será desenvolvido depois, em Nova Iorque, pelo coreógrafo George Balanchine (1904-1983), antigo dançarino da Companhia dos Balés Russos.

O distanciamento dos leitmotiven rítmicos e de uma narração, empregados em alguns balés de Diaghilev, influenciou a compreensão de Villa-Lobos acerca dessa forma de expressão artística, direcionando-o para o balé neoclássico e para o moderno - "um termo que se aplica a qualquer um dos estilos e técnicas de dança teatral, que pretendem apresentações independentes, que se desenvolveram durante o século XX como alternativa às disciplinas rígidas do balé clássico ${ }^{1}$, e cujas pioneiras foram Isadora Duncan (1878-1927) e Ruth St. Denis (1877-1968) (HARRIS-WARRICK et al, 2001). Desenvolvido depois pela coreógrafa americana Martha Graham (1894-1991), entre

\footnotetext{
1 "The term 'modern', or 'contemporary', dance is applied to any of the styles and techniques of theatrical dancing, intended for independent presentation, that grew up during the 20th century as an alternative to the strict disciplines of classical ballet" (HARRIS-WARRICK et al, 2001).
} 
outros, o balé moderno foca nos sentimentos humanos e influenciou o balé clássico na primeira parte do século XX.

Dessa maneira, examinaremos, em primeiro lugar, a contribuição de Villa-Lobos para a dança e o balé, e focaremos em particular nos gêneros do poema sinfônico - que define Erosão - e do balé. Observamos na obra do compositor que o primeiro gênero se viu às vezes acrescentado pelo segundo, o que se explicaria pelo fato de que ambos apresentam aspectos semelhantes, que mostraremos mais à frente. Depois, apresentaremos uma análise da releitura da música de balé de Villa-Lobos pela coreografia de Luiz Bongiovanni.

\section{Contribuição de Villa-Lobos para a dança e o balé}

Heitor Villa-Lobos foi desde muito cedo introduzido à música clássica, que fazia parte dos gostos familiares, mas também, por outro lado à música tradicional europeia, que possuía um repertório dançante composto por valsa, quadrilha, mazurca e polca. Tocava, entre outros instrumentos, o violão, instrumento emblemático da música popular brasileira àquela época e sua porta de entrada no universo do choro (BEHAGUE, 1994, p. 4). Entre 1908 e 1912 compôs a Suite Popular Brasileira: "Mazurka-Choro", "Scottisch-choro", "Valsa-choro", "Gavota-choro" e "Chorinho" (BEHAGUE, 1994, p. 134). A música popular com característica dançante e as danças improvisadas dos blocos de Carnaval e do folclore no Rio de Janeiro e no interior do Brasil proporcionaram os primeiros contatos do compositor com a dança. Além disso, durante suas viagens pelo Norte e Nordeste do Brasil, entre 1905 e 1912, Villa-Lobos familiarizou-se com danças folclóricas brasileiras, chegando a afirmar: - "O folclore, sou eu” (MARIZ, 1989, p. 150); essa experiência causou grande impacto na sua maneira de compor.

O que chama a atenção na sua produção artística é como o balé e a dança são associados à natureza e usados para representá-la. Por exemplo, na Bachianas Brasileiras $n^{\circ} 5$ (1938), o segundo movimento, adicionado em 1945, se chama 'Dança' e se refere ao 'martelo', gênero poético-musical nordestino. O texto de Manuel Bandeira, criado a partir da melodia proposta por Villa-Lobos, evoca o canto de pássaros brasileiros (BÉHAGUE, 1994, p. 118). Além disso, nos seus balés, gênero então em voga na época, a floresta passa 
a marcar presença no palco com Amazonas, Uirapuru e mais tarde Erosão (BEAUFILS, 1988, p. 119).

O contato de Villa-Lobos com o balé é marcado por encontros e colaborações com personalidades e artistas famosos. O compositor foi influenciado pela nova dança, natural e espontânea, de Isadora Duncan, e mais tarde pela Dance Company de Merce Cuningham (LAGO, p. 18-19). Com efeito, Duncan veio ao Brasil realizar cinco récitas em agosto de 1916, acompanhada de uma orquestra com 30 músicos, dirigida por Maurice Dumesnil (BRITO CHAVES, 1971, p. 270). Além disso, outra referência que merece ser mencionada é o balé $O$ Homem e seu desejo, obra com percussão e ritmos brasileiros que se caracteriza por sua dimensão espacial e por sua politonalidade, criado pelo compositor francês Darius Milhaud e pelo diplomata e poeta de mesma origem Paul Claudel, durante a missão diplomática deste último no Rio de Janeiro (1917-1919). Apesar desse balé ter estreado em Paris somente em 1921, com os Balés Suecos, Villa-Lobos possivelmente teve conhecimento de sua existência e de suas novidades composicionais, pelo contato com Milhaud no Rio.

Acreditamos que o balé foi entendido por Villa-Lobos como um meio para representar a natureza e a identidade nacional, não obstante a influência dos Balés Russos de Diaghilev estar presente na obra que marca seu primeiro contato com o balé: o Carnaval das Crianças (1922), com cenários de Di Cavalcanti. Dentre integrantes dos Balés Russos, o compositor conheceu o dançarino norueguês Adolph Bolm, Serge Lifar ${ }^{2}$ - que coreografou Jurupary (1934), e Leonid Massine, tendo mais tarde conhecido o coreografo norte-americano de origem mexicana José Limón - que coreografou $O$ Imperador Jones (1956). Villa-Lobos, portanto, é o compositor brasileiro que abriu caminho para a criação de um balé nacional a partir de um recorte modernista.

Heitor Villa-Lobos compôs várias "danças", como as Danças Características Africanas $^{3}$ (1916 - 'Danças dos Índios Mestiços do Brasil': 'Farrapos', 'Kankukus' e 'Kankikis' (sobre temas musicais dos índios Caripunas, do Estado do Mato Grosso),

\footnotetext{
${ }^{2}$ Villa-Lobos dedicou seu Uirapuru a Serge Lifar, coreógrafo de Jurupary, com quem o compositor iniciou uma amizade em 1933, enquanto o dançarino estava na América do Sul. Dedicou também a Serge Lifar o ballet O Papagaio do moleque, composto em 1932 e cuja estreia aconteceu em 1948.

${ }^{3}$ As Danças Características Africanas foram tocadas na Semana 1922 e se destacaram por representar aspectos brasileiros (KIEFER, p. 93).
} 
Dança Frenética (1918) e Dança dos Mosquitos (1922). ${ }^{4}$ Ademais, sua produção abarcou também doze poemas sinfônicos e/ou balés ${ }^{5}$, além de obras infantis que envolvem a dança como, Caixinha de Boas Festas (com partes do Carnaval dos Crianças), poema sinfônico e balé (1932), e Mandu-Çarará, balé infantil com coro misto e canto, no idioma nheengatu (1940). Houve também projetos e criações não concretizados ou encenados, como O Carnaval das crianças (1922) com Adolph Bolm e Di Calvacanti, Funil e Veículo (1927-1930) com Oswald de Andrade e Tarsila do Amaral, Hino à Beleza e a Menina e o vento, nos anos 50, com Leonid Massine, Rudá (Dio d'Amore), poema sinfônico e balé (1951), e Gênesis, balé (1954). Além disso, podemos mencionar outras obras menos conhecidas com manuscritos extraviados, tais como Danças Aéreas (1914), Funil (1929), Serpente (1920), Vagalume (1920), entre outras.

Apesar dos projetos que não tiveram andamento, dos manuscritos extraviados e das obras poucas conhecidas, Villa-Lobos se impõe como um compositor de música de balé. A dança ocupa, com efeito, um espaço significativo na sua produção que compreende uma experimentação rítmica, diálogos rítmicos. Assim, Jurupary - balé encomendado pelo coreografo Serge Lifar a partir do Choros $n^{\circ} 10$ ('Rasga coração'), com texto onomatopaico de caráter indígena - define um arranjo musical baseado na dança, dentro de uma tentativa de se criar um bailado nacional. Gênesis foi uma encomenda especial da bailarina negra norte-americana Janet Collins. A própria Collins, aliás, dera ao Maestro o título da obra e o argumento, dançando e criando com seu corpo as sugestões que deveriam dar vida à partitura. Infelizmente, o compositor e a bailarina não viram concretizar o balé que só estreou no Rio em 1969 (MARIZ, 1989, p. 156).

Com efeito, a dança lhe inspira diálogos e encontros de vários elementos da natureza e do mundo físico, com vários ritmos, qualidades e movimentos. Podemos emitir a hipótese de que os projetos não concretizados podem se explicar pelo fato de que eram imaginados com coreógrafos e bailarinos de passagem pelo Brasil, deixando pouco tempo para a criação e, em consequência, às vezes, apontando para a necessidade de se recorrer

\footnotetext{
${ }^{4}$ Essas danças foram gravadas pelo maestro Roberto Duarte em 1994, pelo selo Marco Polo, com a Orquestra Sinfônica da Rádio Eslovaca (Bratislava).

${ }^{5}$ Centauro de Ouro (1916), O Naufrágio de Kleônicos (1916), Iara (1917), Amazonas (1929), Uirapuru (1934), Jurupary (1934), Dança da Terra (1939), Rudá (1951), Gênesis (1954), O Imperador Jones (1956), A Floresta do Amazonas (1958).
} 
à música já escrita. Nem sempre se tratava de encomendas reais, mas antes de oportunidades encorajadas por encontros com outros artistas.

A seguir, analisaremos como estas experiências com o balé e a dança se realizaram nos gêneros musicais de poema sinfônico e balé que compartilham semelhanças, antes de classificar as obras de Villa-Lobos ligadas à dança de acordo com sua origem e execução: se foram pensadas originalmente para o balé ou se acabaram sendo coreografadas depois por coreógrafos; o que é inclusive uma das caraterísticas do balé no século $\mathrm{XX}$, criar coreografias em músicas pré-existentes não necessariamente compostas para o balé. Depois, veremos colaborações entre Villa-Lobos e coreógrafos no que concerne à realização de balés e, por fim, tentaremos definir sua apropriação da dança na sua composição de balé.

\section{Poema sinfônico e balé}

Observa-se que ao gênero de poema sinfônico vem assim se acrescentar outro, aquele do balé, que não é sempre mencionado nas partituras quando a obra musical foi adaptada posteriormente. Uma vez aproximado de Amazonas e Uirapuru na Trilogia Amazônica, estamos tentados a considerar Erosão, composto em 1950, como sendo um poema sinfônico e balé, que são gêneros similares na produção de Villa-Lobos. Além disso, nesse momento, Villa-Lobos compunha outros balés.

Esses dois gêneros compartilham, com efeito, similitudes a respeito das fontes de inspiração, da estrutura e da duração. O gênero poema sinfônico que se desenvolveu entre 1840 e 1920 coloca a música em relação com o mundo exterior ao se referir a fontes literária e filosófica ou ainda lendas com detalhes descritivos (MCDONALD, 2001). Da mesma forma, o balé romântico combina história de amor de personagens concretas, aldeões, cavaleiros, com o exótico e o supranatural de acordo com uma organização narrativa.

O poema sinfônico no século XIX não se refere necessariamente a um tema pitoresco, mas com Villa-Lobos, no século XX, é sempre associado a movimentos físicos da natureza e aos sentimentos do ser humano - inspirados por uma lenda ou fonte literária, mas que não servirá de quadro teórico - assim como o faz com o balé. Ao mesmo tempo, enriquecidos pelas descobertas feitas, no século $\mathrm{XX}$, na psicanálise e pela nova 
compreensão do movimento dançado para o qual contribuiu o dançarino e coreógrafo Rudolf Laban (Pressburg, atual Bratislava, 1879 - Inglaterra, 1958), o balé neoclássico e o balé moderno se preocupam com as estruturas do corpo humano e com a relação deste com outros corpos, se referindo, de forma distinta, a movimentos corporais que não têm alcance narrativo, remetendo então a eles mesmos. Assim, a dança neoclássica tentará suavizar as regras da dança clássica trabalhando, entre outros, com o deslocamento dos quadris, o relaxamento da coluna, formas angulares e a geometria dos deslocamentos dos dançarinos, mantendo certa distância com respeito à música, enquanto a dança moderna, por sua vez, buscará explorar os sentimentos do ser humano. Além disso, no século XX, "a música programática e o uso da metáfora perderam espaço como modelo de apreciação teórica" (SALLES, 2009, p. 186). O som e as estruturas sonoras que caracterizam o modernismo se tornaram, em efeito, a nova referência no século XX e são esses elementos que a coreografia de Bongiovanni considerou na obra Erosão. Por isso, ao compartilhar um mesmo "modelo de apreciação teórica", agora pelas estruturas sonoras e rítmicas, poema sinfônico e balé se tornam quase sinônimos em Villa-Lobos. Nesse sentido, o poema sinfônico se define num movimento único e contínuo, como o balé moderno no século XX, ambos raramente excedendo trinta minutos.

No início da produção de Villa-Lobos, o imaginário composicional é mais europeu, grego, com Myremis, Centauro de Outro e Naufrágio de Kleônicos. Depois, esse imaginário modificado pela Semana 22, entre outros, se torna mais amazônico, 'nacional'; e com a influência dos Ballets Russos, o segundo gênero vai se afirmando ou tomando mais sentido num contexto também de formação do balé brasileiro. Assim, Myremis, poema sinfônico, se tornou Uirapuru, balé, em 1934, e da mesma forma, Alvorada na Floresta se tornou Amazonas, balé, em 1929. A posteriori, alguns dos seus poemas sinfônicos e balés seriam mais conhecidos como balé, o que se explica pelo fato de terem sido coreografados durante o século XX e no século XXI. É o caso de Amazonas e Uirapuru.

Na produção musical de Villa-Lobos, existem obras originalmente pensadas para o balé e outras posteriormente adaptadas por iniciativa de coreógrafos. Observamos que as coreografias compostas sobre música de Villa-Lobos não necessariamente destinadas em primeiro lugar para a dança ou o balé foram criadas sobre suas mais populares obras, aquelas mais conhecidas de sua produção, como o Choros $n^{\circ} 10$ (Jurupary por Serge 
Lifar), as Bachianas (Yara por Circé Amado) e a Suite Popular Brasileira (Le Médaillon pelo Ballett School, de Amsterdã). Esse fato acaba levantando indagações sobre a circulação, na época, dessas obras e o acesso dos coreógrafos e outros às partituras originais do compositor, uma trajetória dos usos referentes a esses materiais que permanece ignorada ou incógnita mesmo hoje. ${ }^{6}$

Obras originalmente pensadas para o balé pelo próprio Villa-Lobos:

- Dança da Terra, balé com coro a 6 vozes percussão (1939);

- Caixinha de Boas Festas (com partes do Carnaval dos Crianças), poema sinfônico e balé (1932);

- Mandu-Çarará ${ }^{7}$ balé infantil com coro misto, texto em idioma nheengatu (1940);

- Rudá (Dio D’Amore), poema sinfônico e balé (1951);

- Gênesis, balé (1954);

- O Imperador Jones, balé (1956);

- A Floresta do Amazonas, poema sinfônico e balé (1958).

Obras originalmente pensadas para poema sinfônico e outros gêneros e readaptadas depois pelo próprio compositor para o balé:

- Amazonas, poema sinfônico (Tedio da alvorada /1917) e balé (1929);

- Uirapuru, (Myremis) poema sinfônico e balé (1917/1934);

- Choros $n^{\circ} 10$ (1925), com citação do Schottisch 'Yara' de Anacleto de Medeiros, com letra de Catulo da Paixão Cearense, 'Rasga Coração', balé (1934). Coreografia: Jurupary por Serge Lifar (1934).

Obras posteriormente adaptadas por iniciativa de coreógrafos:

\footnotetext{
${ }^{6}$ Os coreógrafos, citados em nossa introdução, que trabalharam à criação da Trilogia Amazônica não conheciam as obras musicais que coreografaram.

7 "Balada dramática de 1940. Lenda recolhida por Barbosa Rodrigues com os indígenas do Rio Solimões: uma lenda amazônica, - uma lenda de crianças [rica e complexa]". No original: "Ballade dramatique de 1940. Légende recueillie par Barbosa Rodrigues chez les aborigènes du Rio Solimões : une légende amazonienne, - une légende d'enfants [riche et complexe]" (BEAUFILS, 1967, p. 135).
} 
- Divertimento (1936?).

- Coreografia: Flor do Ipê, por Pierre Michailowsky e Vera Grabinska (1937).

- Estreia: Theatro Municipal de Rio de Janeiro, 11 de dezembro de 1937.

- Bachianas Brasileiras $n^{\circ} 4$ (piano) e $n^{\circ} 7$ (orquestra, 1942).

○ Coreografia: Yara, por Circé Amado (1961). ${ }^{8}$ Balé em três partes, criação e argumento de Harald Lander. Adaptação do livro de Circé Amado. Cenário: Fernando Pamplona e figurinos de Mme. Kalma Murtinho.

- Estreia: Theatro Municipal de Rio de Janeiro, 11 de setembro de 1960.

- Suite sinfônica (1936).

- Coreografia: O Descobrimento do Brasil ${ }^{9}$ por Eugênia Feodorova e Tatiana Leskova (2016). Poema coreográfico e concepção do balé por Circé Amado. Cenografia de Gianni Ratto. Direção orquestral: Alceu Bocchino.

- Estreia: Theatro Municipal de Rio de Janeiro, 12 de dezembro. Semana Villa-Lobos.

\footnotetext{
${ }^{8}$ Ao atravessar uma floresta, um jovem moço encontra a legendária Iara, meio-mulher, meio-peixe. Apaixona-se por ela e nunca mais volta das águas. Circé Amado era então assessora do setor dança na comissão de música no Conselho Nacional da Cultura no Rio de Janeiro. Não encontramos muitas informações sobre ela. Acesso em: https://issuu.com/jornaloexpresso/docs/jornal_25_de_fevereiro/7. Consultado em 21/08/2020.

${ }^{9}$ Encontro de dois povos simbolizados pelas personagens da história. $1^{\circ}$ quadro: partida dos Portugueses; $2^{\circ}$ quadro: sua viagem; $3^{\circ}$ quadro: os mitos, a descoberta dos índios; $4^{\mathrm{e}}$ quadro: procissão e missa. "Hoje, a Circe Amado, Gianni Ratto, Tatiana Leskova, Eugenia Feodorova e demais participantes da criação do balé "O descobrimento do Brasil", que encerra as comemorações da Semana Villa-Lobos, e será apresentado hoje a noite no Theatro do Rio de Janeiro". (Tiremos o chapéu. A Última Hora, Segunda-Feira, 12 de dezembro de 1960).
} 
- Suite Popular Brasileira (1908-1912 e 1923), Movimentos: "schottischchoro"; "valse-choro"; "gavotte-choro"; "valsa-choro"; "mazurka-choro". Coreografia/Balé filme ${ }^{10}$ : Le Médaillon por Balletschool Almere, em 2014.

- Alvorada na Floresta tropical, abertura (1953). Coreografia: $1^{\mathrm{a}}$ parte do balé, “Alvorecer na floresta”, por Marcelo Gomes, em 2016.

Observamos aqui que a produção musical eclética de Villa-Lobos inspirou um balé neoclássico. É o que afirma a bailarina brasileira Circé Amado em 1961: “A música de Villa-Lobos começou a me sugerir ballets, meu desejo tornou-se fazer ballets, a arte que eu aprendera na civilizada Europa, com essa música que [tinha marcado a] minha infância" (CORSEUIL, 1961, p. 3). Assim, as Bachianas Brasileiras $n^{\circ} 4$ e $n^{\circ} 7$, por serem caracterizadas pelo estilo neoclássico, sugeriram a criação de Yara.

De obras colaborativas de Villa-Lobos, podemos mencionar Jurupary (1934), Rudá (1951), Gênesis (1954) e O Imperador Jones (1956). Encomendada para o balé, Jurupary seria mais uma 'colagem' ou uma adaptação musical para o balé enquanto as demais são composições musicais para o balé.

Jurupary (1934), ou "mito do fogo", é o resultado de uma colaboração de VillaLobos com o coreógrafo Serge Lifar e o pintor brasileiro Cícero Dias. Emocionado pela música de Villa-Lobos, Serge Lifar, então diretor da Opera de Paris, pediu ao compositor brasileiro para imaginar um balé sobre o Choros $n^{\circ} 10$. Villa-Lobos enviou um libreto que inicialmente Lifar não aprovou, mas acabou aceitando, após nova versão realizada

\footnotetext{
${ }^{10}$ Coreografada pelo Balletschool Almere de Amsterdam para o balé filme, Le Médaillon, onde há uma associação do violão de Villa-Lobos com a dança clássica. Disponível em: https://www.youtube.com/watch?v=trKh1yWmJJg. Acesso em: 21 mar. 2019. Guitar: Roel Goedhart; Regie \& script: roswitha Commandeur; Camera, audio e editing: Frank Reijgersber; Dançarinos: Donna Samson, Renze Samson, Thijs Wolff, Nina Plantefève-Castryck, Kris Siekerman, Johan Christensen, Machteld van Acker, Paola Inguaggiato, Gonny Sanders, Wil Heins. "O brasileiro Heitor Villa-Lobos (1887-1959) é um compositor altamente aclamado, principalmente por sua obra para o violão clássico. Em sua Suite Popular Brésilienne, uma mistura de estilos clássicos, europeus e música folclórica brasileira, este curta metragem assume a inovadora combinação de violão clássico com balé. $\mathrm{O}$ que é especial é que o filme contém uma performance do "Valse-Chôro", uma parte redescoberta da suíte que foi publicada recentemente [por Frederic Zigante nos arquivos de Max Eschig em 2006]. Dança e música são trazidas para um todo original através de uma história convincente sobre amizade". Texto original, em inglês: "Brazilian Heitor Villa-Lobos (1887-1959) is a highly acclaimed composer, not least because of his oeuvre for the classical guitar. In his Suite Popular Brésilienne, a mix of classical, European styles and Brazilian folk music, this short film engages in the innovative combination of classical guitar with ballet. What is special is that the film contains a performance of the Valse-Chôro, a rediscovered part of the suite that was only recently published. Dance and music are brought to an original whole through a compelling story about friendship".
} 
por Victor de Carvalho. Essa obra caracteriza-se como um arranjo musical motivado pela dança, a partir de uma encomenda feita por um coreógrafo.

O compositor brasileiro parte do Choros $n^{\circ} 10$, composto em 1926, agregando como tema central o Schottish 'Yara', de Anacleto de Medeiros, que, após receber letra de Catulo da Paixão Cearense, passou a ser conhecido como 'Rasga coração' (DIAS, p. 229).

Além disso, a peça foi concebida na tentativa de se criar um bailado nacional, uma criação índio-brasileiro (PEREIRA, 2005, p. 109).

\begin{abstract}
A experiência de construção de um 'bailado nacional' também teve contribuição de Serge Lifar, importante coreógrafo e bailarino ucraniano radicado na França. Em 1934 o bailarino encenou Jurupari de Villa-Lobos no Municipal do Rio de Janeiro e sua passagem pelo país mostra a estreita relação entre as artes, o desejo modernista de traduzir uma estética nacional e o balé que caminhava para a estética da dança moderna. [...] Cinco anos depois Cícero Dias também elaboraria os figurinos de Maracatu de ChicoRei. As fotos da encenação de Jurupari e os desenhos dos figurinos de Maracatu mostram a profunda inspiração em elementos das culturas indígenas e afro-brasileiras e a ruptura com alguns padrões estéticos do balé clássico (CARLONI, 2014, p. 178).
\end{abstract}

Assim, nesta obra, se revelam elementos telúricos, expressos pelos ostinati e pela polirritmia. Villa-Lobos, que "[só] pensava na música que o Serge Lifar ia dançar" (DIAS, p. 53) e que inclusive lhe dedicou seu Uirapuru, fez uso do início da canção paresi Mococê-cê-maká, recolhida por Roquette-Pinto, ambientada anteriormente pelo compositor no ciclo Canções Típicas Brasileiras (1919) (KIEFER, 1981, p. 113); assim, o movimento de dança parece representar o universo indígena e seus rituais.

Durante uma temporada em 1934, Serge Lifar montou Jurupary no Rio de Janeiro. O primeiro ensaio ocorreu no Theatro Fênix. Mais tarde, o balé foi apresentado no dia 20 de setembro 1934, no Theatro Municipal de Rio de Janeiro, ano de sua modernização, na ocasião da festa artística e de despedida de Lifar, ao lado das obras Prometeu, Prelúdio para o Entardecer de um Fauno, Dança Húngara e Divertissements, com regência do maestro Henrique Spedini. Depois do Theatro Municipal de Rio, Jurupary foi apresentado no Theatro Municipal de São Paulo. 
O balé $O$ Imperador Jones ${ }^{11}$ foi encomendado a Villa-Lobos pelo coreógrafo norteamericano de origem mexicana José Limón e define uma releitura da modernidade e do caráter expressionista da obra literária de mesmo nome do dramaturgo Eugene O’Neill. Pela técnica de dança moderna, Limón toma como referência a música de peplo, ${ }^{12}$ então em voga nos Estados Unidos e adaptada por Villa-Lobos. Além disso, "[a] obra expressionista deu [ao compositor] um campo muito amplo para criar a música do seu ballet, em que é indiscutível a presença de ritmos africanos num ambiente ameríndio" (GRIECO, 2009, p. 127). Assim, uma mulher idosa nativa se tornou na partitura musical uma mulher indígena apaixonada e o barulho das correntes dos escravos deu a VillaLobos a oportunidade de experimentar percussões num novo contexto. No entanto, não encontramos correspondências trocadas pelos dois artistas que atestem discussões sobre o processo criativo da obra. Ao mesmo tempo, observa-se que esse trabalho representa uma produção um pouco isolada, no que concerne ao tema, se comparada a outras criações de Villa Lobos. Uma análise da dramaturgia da obra e das relações música-dança mostram que Villa-Lobos compôs, de maneira fiel, somente a partir da obra literária, conservando dessa as informações ligadas à psicologia, aos sentimentos e movimentos corporais das personagens, e que Limón coreografou a partir do texto e da música, sem seguir stricto senso as indicações do compositor sobre as ações das personagens. Por isso, ao trabalhar separadamente sobre um tema, o da desintegração de um indivíduo pelo terror, este balé remete a uma colaboração tradicional, à maneira dos Balés Russos.

Apesar de ter sido um projeto que não foi levado adiante e da pouca informação que temos a respeito do contexto de criação do balé Gênesis (1954), a declaração reproduzido abaixo, do musicólogo Vasco Mariz, nos convida a pensar que teria sido uma colaboração criativa à imagem daquelas experimentadas pelos casais StravinskyBalanchine e Cage-Cunningham, onde a preocupação se concentra nas relações músicadança e em sua retroalimentação; a linguagem de um e do outro influencia reciprocamente nos processos criativos.

\footnotetext{
11 “A evolução de seus oito quadros mostra a fuga do negro Brutus Jones de um presídio e sua chegada a uma ilha do Caribe, onde acaba por ser feito Imperador. Mas há rebeldia na população local e ameaçado de morte, Jones planeja uma fuga para a Martinica. Na floresta que tem de percorrer, sofre alucinações sob a forma de autômatos mudos. As alucinações sucedem-se ao som do tã-tã dos rebeldes, até a morte do protagonista" (GRIECO, 2209, p. 127).

${ }^{12}$ A expressão "música de peplo" se refere à ambientação pensada na Antiguidade grega ou romana, em referência às túnicas sem manga usadas àqueles tempos.
} 
Encomenda especial da bailarina negra norte-americana Janet Collins. A própria bailarina dera ao Maestro o título da obra e o argumento, dançando e criando com seu corpo as sugestões que deveriam dar vida a partitura. Infelizmente, o compositor e a bailarina não viram concretizar o balé que só estreou no Rio em 1969 (MATRIZ, 1989 p. 156).

Estas obras encomendadas por profissionais da dança estrangeiros, entre as quais duas correspondem à sua fase americana ${ }^{13}$, demostram seu reconhecimento no exterior.

Observa-se que as obras pensadas inicialmente para o balé são obras tardias na sua produção, o que testemunharia um resultado de sua experiência com balé neoclássico e moderno no Brasil e durante suas estadias na Europa e nos Estados Unidos. Por 'sua estética antirromântica', Villa-Lobos, com efeito, não compôs a partir de uma narração fornecida por um livreto, como é o caso do balé romântico, nem atribuiu associações rítmicas, típicas das coreografias de Diaghilev das quais se afastou (AZEVEDO, 2016, p. 211).

\footnotetext{
Villa-Lobos opõe isso, e não sem imensa insolência, aos ritmos 'construídos' dos quais vive a coreografia de Diaghilev.

Aqui, talvez a dança tenha amadurecido uma noção basicamente plástica e indivisa de 'personagens rítmicos', que Beethoven foi o primeiro a abordar. Essa coreografia de ritmos figurativos teria sido a última possível para Villa-Lobos ${ }^{14}$ (BEAUFILS, 1967, p. 115).
}

Não se trata, portanto, de leitmotiven rítmicos ou melódicos, como foi o caso com Uirapuru, uma concepção talvez mais próxima do balé de Diaghilev e oposta inclusive nesse respeito a Amazonas, que a precedeu (MARIZ, 1989, p. 150).

O caso de Rudá (Dio d'Amore) - mesmo que a obra tenha sido composta depois, em 1951 - nos informa sobre um distanciamento do balé romântico que já encontramos nos seus primeiros balés. Assim, de acordo com Zito Batista Filho, citado por Vasco Mariz, não há "argumento literário nem ideia teatral" (MARIZ, 1989, p. 154) nesse bailado, composto de cinco quadros que retratam as aventuras do deus tupi de amor com vários povos das américas pré-colombianas, Maias, Astecas, Incas, e Marajoaras-

\footnotetext{
${ }^{13}$ A cronologia da vida de Villa-Lobos, elaborada pelo Museu Villa-Lobos, mostra que a experiência americana do compositor iniciou nos anos 1944. Disponível em https://museuvillalobos.museus.gov.br/cronologia/. Consultado em 07/12/2020.

${ }^{14}$ Tradução para o português pela autora. "Villa-Lobos s'oppose en cela et non sans une immense insolence, aux rythmicités 'construites' dont vit la chorégraphie de Diaghilev. Ici peut-être la danse a-t-elle mûri une notion avant tout plastique et indivise de 'rythmes-personnages' dont Beethoven le premier s'était tellement approché. Pareille chorégraphie de rythmes figuratifs eût été pour Villa-Lobos la dernière possible."
} 
Nheengatu ${ }^{15}$. Villa-Lobos, na verdade, sublinha: "procurei fugir dos processos de estrutura dos Bailados, que vêm desde a França do século XVIII, tendo sido um pouco transfigurados por Diaghilev. Aqui temos a dança pela dança" (MARIZ, 1989, p. 155); o que demostra uma postura distanciada a respeito dos códigos do balé tradicional e uma apropriação criativa da dança compreendida como ferramenta composicional. Não obstante, a obra nunca foi coreografada por causa de sua complexidade. Acreditamos, porém, que de acordo com o estilo musical, mais próximo de $O$ Imperador Jones ${ }^{16}$, inspirado pela "música de peplo", a releitura coreográfica estaria mais na linha do balé moderno.

"A dança pela dança" significa que o compositor integra a dança no seu processo composicional, movimentos corporais e/ou movimentos de conjunto de dançarinos, neoclássicos - de técnica clássica com novas flexibilidade - ou modernos - contrações do corpo, uso da gravidade, saltos e movimentos no chão - que não se referem a elementos narrativos e que o compositor faz corresponder com sua música. Uma atitude composicional que testemunha uma apropriação da dança parecida com aquela experimentada por Stravinsky quando compôs os balés neoclássicos Apollon Musagète (1928) e Agon (1958), que revela dentro do processo criador um jogo de correspondências entre a música e a dança, duas artes muito próximas. Assim, o ritmo é o 'estar juntos' da música e da dança que compartilham ainda textura, estrutura, forma, qualidade e mimética, nas suas próprias terminologias. Ademais, movimentos de fenômenos naturais e movimentos do corpo dançante se correspondem e se confundem no processo composicional de Villa-Lobos. Por sua natureza, portanto, a dança respondeu à preocupação sonora e espacial compositor - "justaposição, recorte, decomposição de ideias musicais que entram em ressonância entre si" (SALLES, 2009, p. 187) - e deu ao compositor a possibilidade de se libertar dos leitmotiven e das estruturas literárias ao achar pontos de referências nas estruturas sonoras e rítmicas.

\footnotetext{
15 "É um guerreiro que reside nas nuvens, suscita o amor no coração dos homens, provoca a saudade do torrão natal quando eles se afastam de suas tribos e os conduz de volta de suas peregrinações. Rudá tem dois satélites, divindades inferiores, Cairé que é a lua cheia e Catiti, a lua nova. A rigor, três luas distintas. A adaptação de Villa-Lobos é livre e estende-se dos marajoaras-nheengatu de Couto de Magalhães aos maias, incas e astecas" (GRIECO, 2009, p. 121-122).

${ }^{16}$ Idem, p. 121. "O último quadro foi retirado da obra e incluído no final do bailado Emperor Jones".
} 
A atitude moderna e a compreensão afinada com movimentos naturais, sempre ligadas a uma preocupação de retratar a natureza brasileira, se encontram plenamente efetivadas em Erosão, acreditamos, o que é confirmado por sua primeira releitura coreográfica realizada por Luiz Bongiovanni ${ }^{17}$. O coreógrafo paulistano deu à obra de Villa-Lobos uma dimensão ecológica e política ao propor o debate sobre a catástrofe de Mariana, ocorrida em 2015 no estado de Minas Gerais ${ }^{18}$.

Elaboramos a análise a seguir a partir de nossa experiência in loco no Theatro Municipal do Rio de Janeiro, durante a criação do balé, entre junho e julho de 2016, depois do qual houve duas entrevistas, uma escrita e uma oral, com, respectivamente, o coreógrafo e Manoel Francisco, professor e mestre de ballet nesse Theatro que foi o ensaiador da coreografia. Para nossa análise, nos referiremos às análises de Paulo de Tarso Salles e de Marlene Migliari Fernandes sobre a música de Erosão.

\section{Princípios coreográficos: conflito e corte}

Recolhida por João Barbosa Rodrigues (1890), Poranduba Amazonense ${ }^{19}$ (RODRIGUES, 1890, p. 211), a lenda indígena que inspirou o poema sinfônico Erosão conta a história da criação de um rio, o rio Solimões - trecho superior do rio Amazonas em confluência com o rio Negro, pelas lágrimas da lua que chora o sol.

As lágrimas da lua não podiam se misturar com a água do mar que embraveceu, enquanto na terra que acabava de percorrer as lágrimas da lua se criou um rio. Temos desta lenda um processo de degradação da terra, uma erosão, a terra deixando lugar à água, e dois elementos em conflito: terra e água.

Ao tomar conhecimento do título da obra musical, o coreógrafo Luiz Bongiovanni fez a ligação com a catástrofe ecológica acontecida no Brasil, em 2015, a 'Tragédia de

\footnotetext{
${ }^{17}$ Graduado em Filosofia e Mestrado no Instituto de Artes da UNICAMP. Atuou durante dez anos como bailarino profissional em várias companhias da Europa. Atualmente, é diretor e coreógrafo do Núcleo e Pesquisa Mercearia de Ideias (São Paulo).

${ }^{18}$ Recomendamos que o leitor assista o trecho do balé para ter uma ideia do conjunto. Disponível em https://www.youtube.com/watch?v=h5nyGlPqzwo. Acesso em: 11/02/2020.

${ }^{19}$ Essa lenda se encontra na terceira parte, 'Contos astronômicos e biológicos', de Poranduba Amazonense. $\mathrm{Na}$ partitura musical editada por Max Eschig, é escrito: Lenda Amerindia $\left(\mathrm{N}^{\circ} 1\right)$ Erosão, Sorimão U Ipirungáua (A origem do rio Amazonas). Em Poranduba Amazonense, é escrito: "A origem do rio Solimões".
} 
Mariana, ${ }^{20}$, no Estado de Minas Gerais. “A erosão de Mariana não foi apenas de ordem física, mas de ordem moral, explicitando a usura que parece prevalecer em grandes negócios e a sensação de grande erosão moral que estamos vivenciando" declara o coreógrafo paulista (INFORMAÇÃO VERBAL). Portanto, a obra coreográfica, cujo cenário apresenta fotografias da maior catástrofe ambiental ocorrida no Brasil, questiona a responsabilidade do ser humano e as consequências da ação do homem no planeta. As fotos dos fotógrafos Luciano Costa e Rafael Simioni (Fig. 1 e Fig. 2) que testemunham esse desastre foram assim essenciais para a reflexão do coreógrafo que ficou chocado pela marca marrom da sujeira que a lama deixou no horizonte.

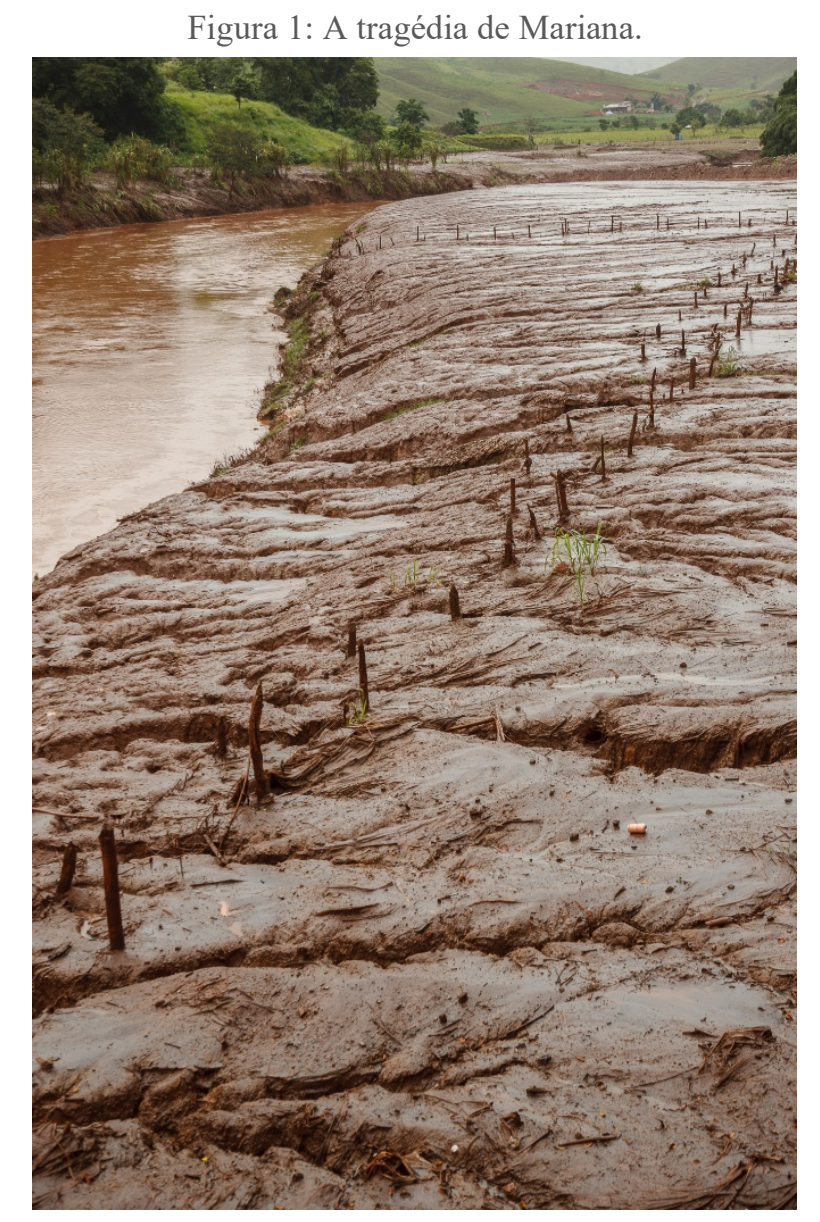

Fonte: SIMIONI, Rafael Lazzarotto; COSTA, Luciano B. O vale, a Vale e a lama, 2016. Cortesia do acervo pessoal dos autores.

\footnotetext{
${ }^{20} \mathrm{E}$ à qual se agrega a tragédia de Brumadinho, ocorrida em janeiro de 2019. O rompimento da barragem de Mariana ocorreu no dia 5 de novembro de 2015. O colapso dessa barragem causou um fluxo de milhões de rejeitos de mineração. A lama formada percorreu mais de $20 \mathrm{~km}$ e devastou o Rio Doce, onde se cristalizou, matando pessoas e a vida marinha. (MINISTÉRIO PÚBLICO FEDERAL).
} 


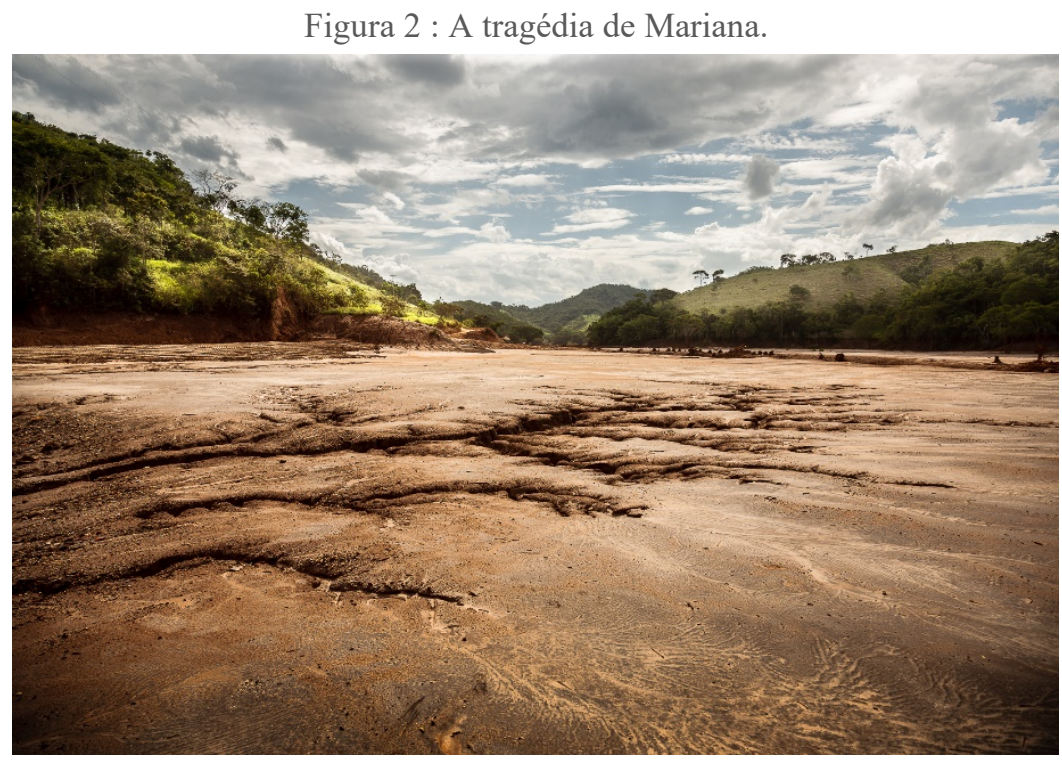

Fonte: SIMIONI, Rafael Lazzarotto; COSTA, Luciano B. O vale, a Vale e a lama, 2016. Cortesia do acervo pessoal dos autores.

Desta tragédia ambiental com consequências irreversíveis, o coreógrafo imaginou um procedimento coreográfico: o elemento a 'degradar', a técnica clássica, resultando na reformulação de 'preceitos tradicionais', uma postura frente à história característica da dança contemporânea:

\begin{abstract}
A erosão proposta seria da própria técnica clássica, revisitando e transformando preceitos tradicionais como a verticalidade do corpo e da coluna, o controle, a precisão e organicidade do todo em opostos possíveis, isto é: sinuosidade ou mobilidade da coluna, impulso e ímpeto na movimentação sem a determinação antecipada do final do movimento, simultaneidade de ações a partir de tarefas especificas e assim por diante (TMRJ, 2016, p. 43).
\end{abstract}

Um diálogo ou conflito entre a 'técnica e seu esgarçamento'; entre a tradição e sua reformulação; entre a terra e a água, que agem como forças opostas e traduzem os sentimentos humanos. Na coreografia, esses dois elementos naturais, essa dicotomia, se transformaram em duas qualidades asseguradas tanto pelos dançarinos como pelas dançarinas: a figura feminina ${ }^{21}$, definida como liquida, a água; a figura masculina, definida como dura, a lama.

Essa sensação de um corte formado por estes se tornou então um conceito de busca e se revelou nos figurinos. Os collants dos dançarinos foram assim cortados pelo meio,

\footnotetext{
${ }^{21}$ Como observa o musicólogo Paulo de Tarso Salles, o "próprio rio Amazonas foi batizado com uma transposição o mito grego, devido à suposição do explorador espanhol Francisco de Orellana, que batizou o rio em 1541-1542 ao confundir as mulheres indígenas com as guerreiras míticas” (Salles, 2009, p. 188).
} 
em marrom e cinza, e alguns chegaram a usar um cinto da altura do peito que divide a parte de cima e de baixo. Além disso, faixas de várias larguras de tecido branco foram penduradas no palco lembrando talvez retroescavadeiras e arranque de superfícies. A tragédia e suas fotos constituem, portanto, a ligação entre os figurinos, vídeos e cenários. Podemos resumir a proposta coreográfica por este esquema:

Figura 3: Proposta coreográfica.

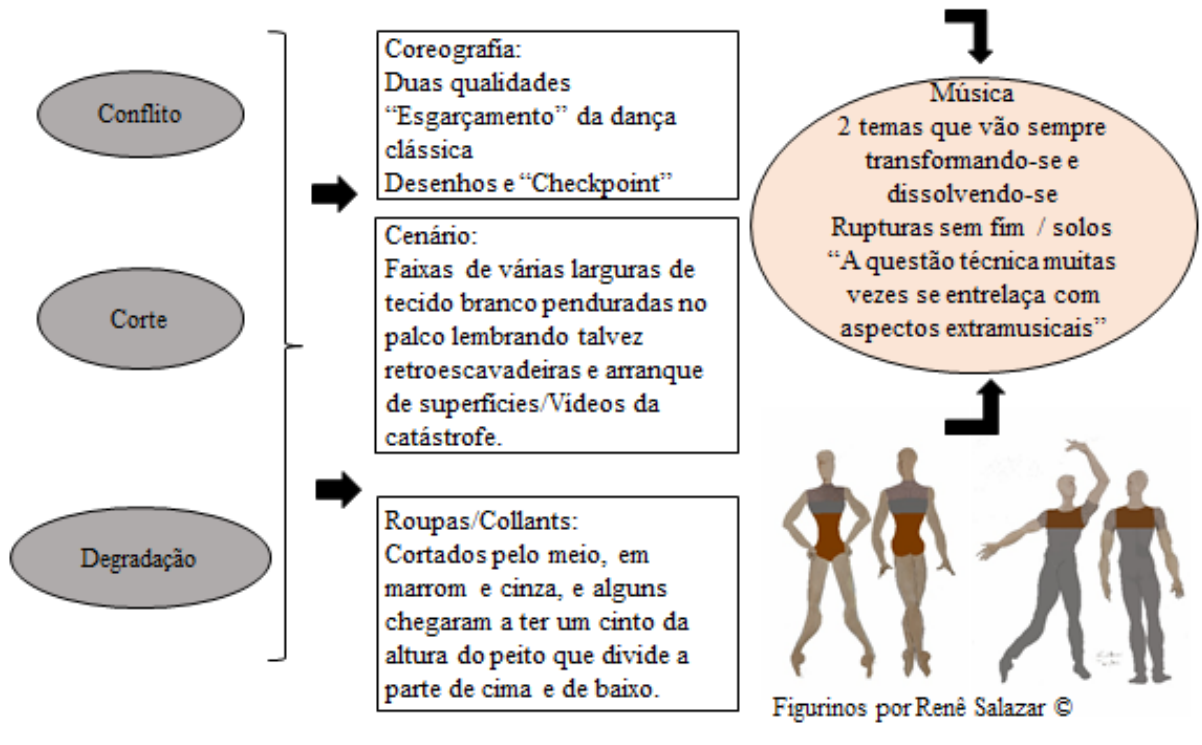

Fonte: produção da autora.

\section{Ferramentas coreográficas: 'checkpoint' e desenhos}

À primeira vista, Erosão não constitui uma obra fácil de entender e coreografar. Não poderíamos, de fato, seguir um tema que voltasse várias vezes da mesma maneira ou com leitmotiven ou ainda que tivesse variações claramente identificadas como foi o caso em Uirapuru, por exemplo. A questão é: como o poema sinfônico, um gênero musical estimulado pelas imagens e por uma fonte literária, associado com o gênero balé, pode representar uma erosão? Uma erosão com o sentido de uma degradação e uma transformação, que de acordo com a fonte literária aí coloca em conflito a água e a terra, o líquido e o sólido.

Como já mencionamos, para nossa demonstração, usaremos a análise da obra realizada por Marlene Migliari Fernandes que apresentou rigorosamente e de forma concisa a unidade e a coerência da obra. A autora distinguiu os componentes auxiliares e os componentes essenciais, ou seja, um $1^{\circ}$ tema e um $2^{\circ}$ tema e suas numerosas variações 
de naturezas variadas - ampliação, antecipação e condensação etc. Os dois temas que surgem logo no início vão se transformando ao longo da obra, com dinâmicas diferentes e variações, ou seja, sempre se modificando. Se alguns falam de 'indeterminação formal' no que diz respeito a um poema sinfônico, com elementos e imagens exteriores assegurando a coerência do poema, a análise da Marlene demonstra o contrário, a disposição composicional sendo aí responsável pela coerência da obra, mas, também, em perfeita harmonia com as imagens que vêm em nossa mente ao pensarmos numa erosão. Trata-se, portanto, de um tema favorável para explorar procedimentos modernos, tais como rupturas sem fim. "A questão técnica muitas vezes se entrelaça com aspectos extramusicais", sublinha Paulo de Tarso Salles, dando como exemplo de sobreposição de várias técnicas a melodia do pássaro em Uirapuru (SALLES, 2009, p. 184).

\section{'Checkpoint'}

Ao focalizarmos a dança, destacamos a recepção da obra musical e sua escuta ativa e sensível. A escuta é uma escritura e, no caso da dança, se faz pelo corpo que considera ou sente formas, dinâmicas e qualidades, realizando-as através de uma técnica adquirida, por movimentos transmitidos pelo coreógrafo já compostos ou achados espontaneamente de acordo com o corpo e o estilo dos dançarinos. A disposição composicional da obra aqui, de estilo moderno - implica uma nova atitude na recepção da música, revelada apenas pela dança. As impressões dos bailarinos, ou seja, a resposta do corpo em contato com a música, nos orientou, com efeito, nesse sentido, mostrando talvez, pela mesma ocasião, a atitude coreográfica de Bongiovanni. "Identificando aos sons", expressa assim uma bailarina, uma compreensão que nos faz pensar a partitura como um espaço sonoro. As palavras de Moacyr Laterza Filho descrevem claramente esse espaço:

O aspecto narrativo, característico do poema sinfônico, dissolve-se, aí, na exploração de materiais sonoros abstratos, em nada descritivos, abordados sob parâmetros então muito modernos, como densidade, volume, tessitura, tímbrica, as sobreposições melódicas e a própria rítmica, trabalhados como elementos de um discurso sonoro próprio. Com isso, e com certas construções melódicas angulosas, Villa-Lobos consegue afastar-se até mesmo da tonalidade (da qual nunca conseguiu de todo se desvencilhar), reinventando-se a si próprio e definindo um caminho autônomo para a Música Brasileira (LATERZA FILHO). 
Assim, os dois temas principais mencionados acima e suas variações devem ser pensados não como motivos melódicos ou frases que nos orientam de maneira linear na música, mas como parâmetros sonoros, ou conjunto sonoro. A impressão que se tem é que os temas e suas variações não se desenvolvem, mas pelo contrário se dissolvem. A escritura da partitura é testemunha disso, pois apresenta numerosos 'solos', pensados como material sonoro cuja vocação é de ser sempre modificado de acordo com vários procedimentos e alturas. A nova atitude consiste em aceitar se deixar guiar pelo 'discurso sonoro', pelo diálogo entre blocos sonoros, com o intuito de se orientar na música por meio da identificação do 'checkpoint', para usar os mesmos termos do coreógrafo.

\section{Desenhos}

A proposta coreográfica vem assim nos ajudar a nos orientarmos na música. E o recurso a desenhos foi uma solução artística e coreográfica para lidar com essa situação. Os desenhos ou também as formas geométricas definem um traçado no espaço físico e musical determinado por uma vontade e uma busca do artista. "Rapazes! Ter noção de desenhos", explica Bongiovanni. Unindo uma forma a um raciocínio - triângulo, quadro, linha, solos, duos e trios -, as ilustrações colocam em movimento a erosão. Através de alguns exemplos, veremos que os desenhos foram usados para juntar os dançarinos, determinar traçados no palco e realizar movimentos corporais. É interessante observar que as formas geométricas deram seu nome às partes a serem trabalhadas durante os ensaios. Eis três exemplos:

Cubo. "Coreografia é estrutura, organização", explica Bongiovanni aos dançarinos. Assim, na parte que nós chamamos de 'Variação dos meninos', estes, então alinhados uns atrás dos outros em triângulos, vão se agrupar até formar um cubo (c. 127-133).

Mandala. No A tempo, após um solo do dançarino, todos se dirigem para o centro do palco para se formar em mandala, (c. 227-288), ou na forma de um caleidoscópio, de acordo com o esquema que nós desenhamos abaixo (Fig. 4): 
Figura 4: Mandala.

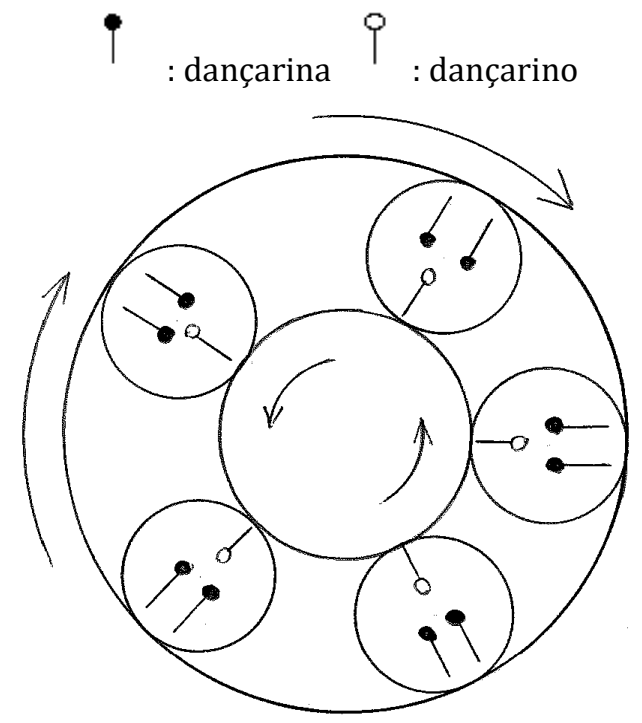

Fonte: produção da autora. Desenho inspirado pela notação coreográfica Benesh.

Temos dois círculos, um grande com um menor dentro, girando em sentidos opostos. O maior é formado por oito dançarinas orientadas para o centro e o menor por quatro dançarinos de costas para o centro, formando assim cinco triângulos.

Letra 'e'. No solo do dançarino, a letra 'e' foi lançada como ideia para um movimento de perna na entrada do dançarino no palco.

\section{Análise da releitura da música pela coreografia}

Nossa análise se divide em oito partes que apresentam as várias etapas da 'erosão', partindo da releitura da música pela coreografia e focando nos elementos musicais considerados pela dança. Observa-se, de um lado, que a cada indicação de movimento se associa uma figura geométrica. Do outro lado, vê-se que solos, duos e trios usados aqui como desenho geométrico são também formas de variação do ballet tradicional que estruturam e ao mesmo servem o princípio de Erosão.

\section{Bloco triangular / Adagio (c. 1-65) ${ }^{22}$}

A primeira parte abre sobre um bloco triangular formado por todos os dançarinos, colocado na parte esquerda, no fundo do palco. Depois, seguirá sua dissolução pelos

\footnotetext{
22 Colocamos entre parênteses as referências dos compassos de acordo com a partitura que usamos para nossa análise, indicada na bibliografia.
} 
deslocamentos e as formações dos dançarinos, que implica um diálogo entre duas texturas: leve e contínuo pelo $2^{\circ}$ Tema, identificado por Marlene Migliari Fernandes (Fig. 5), que se torna pesado e estagnado pela variação [V.2].

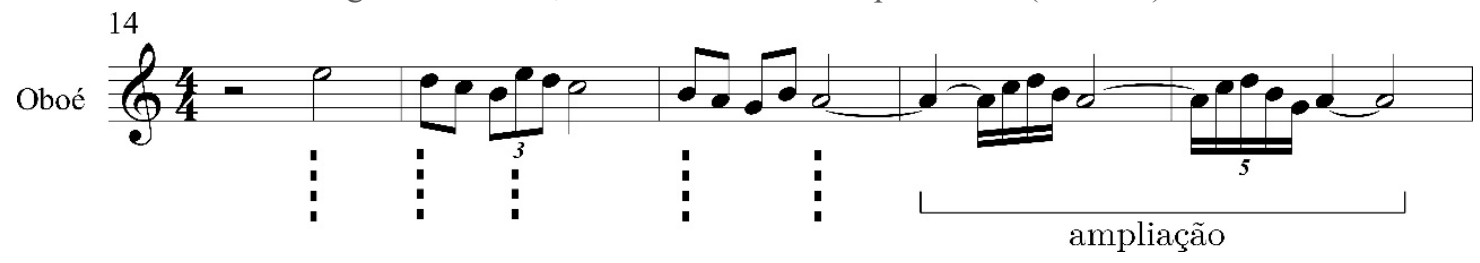

Fonte: FERNANDES, 1999, p. 23.

Nesse tema melódico sustentado pelo pedal de sol nos contrabaixos e precedido por outro tema nos violinos (c. 13-17), o bloco se dissolve e dois casais de dançarinos se espalham em duos no palco, para em seguida voltar ao bloco que se reestrutura e passar para o outro lado do palco, momento em que toca mezzo forte um solo no fagote, numa variação do $1^{\circ}$ tema, que veremos mais à frente. Nesta primeira parte, aparece uma profusão de solos, que chamam mais ou menos a atenção dependendo de suas intensidades - piano, mezzo forte ou forte -, retomados, eles mesmos ou sua variação, por outros instrumentos simultaneamente ou sucessivamente, em várias alturas. Esses solos não claramente numerados na partitura.

Os ostinatos nos sopros, da família das madeiras (c. 23-24), acompanhados pelo pedal do sol nos contrabaixos, nos levam à variação do $2^{\circ}$ tema com acordes acentuados e tocados fortíssimo pelos sopros e instrumentos de metais (c. 25-29) sustentados pelas sextinas de semicolcheias ascendentes e descentes nas cordas. Os bailarinos se formam então em duos.

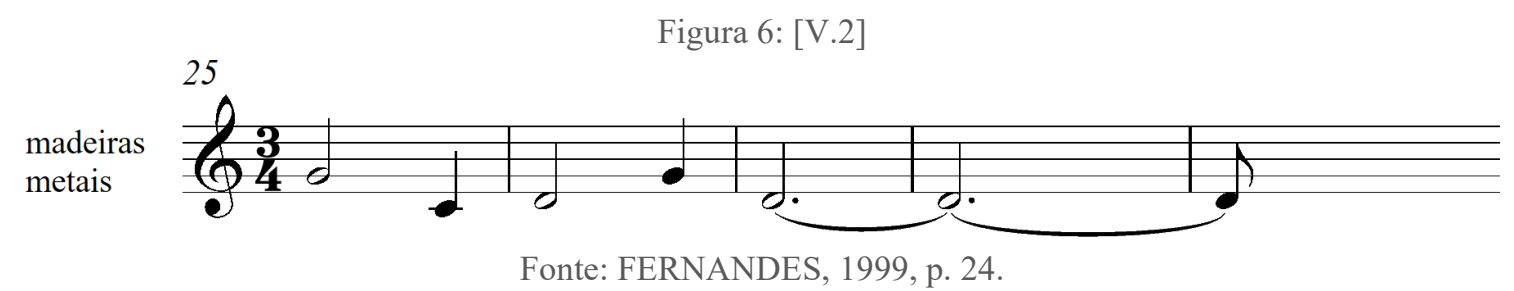

A pesquisadora Marlene Migliari Fernandes mostra que a variação do $2^{\circ}$ tema [V2] é construída em torno do intervalo de quarta: 
Figura 7: Relação de quarta.

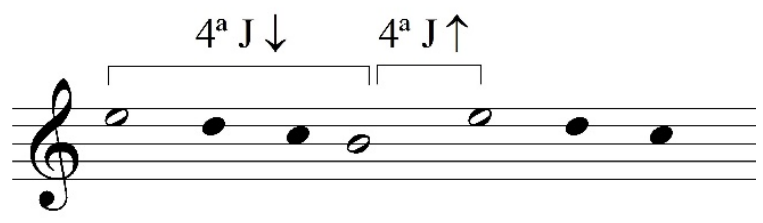

Relação de quarta.

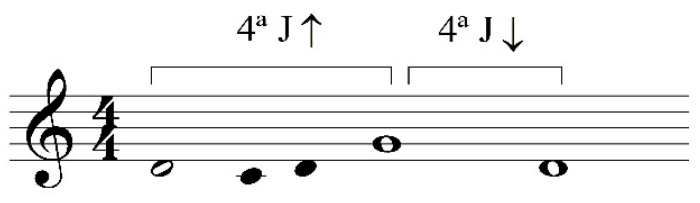

Fonte: FERNANDES, 1999, p. 24.

O $2^{\circ}$ tema, variado, volta no oboé, uma quarta acima (c. 29-36), enquanto uma dançarina inicia um solo se afastando do bloco e então voltando à sua posição inicial. Sua variação [V.2] (c. 33-37) reaparece e os dançarinos se reorganizam em duos antes de deixar o palco. Esse tema é variado (com sua primeira nota ornamentada), ampliado e reapresentado pelas flautas (c. 38-43) com a presença de dois duos de dançarinos no palco; sendo imediatamente retomado pelo oboé (c. 41), em seguida pelas trompas (c. 43), clarinetes (c. 47-49) e, por fim, pelas cordas (c. 50-54), momento em que os dançarinos se dispõem em trios. Depois, a variação do $2^{\circ}$ tema (c. 55-65) volta, ampliada, para terminar a primeira parte, enquanto os dançarinos se combinam novamente em duos. Uma transição (componente auxiliar) é realizada pelas flautas, oboés, clarinetes, fagotes e celesta, levando ao Adagio.

Os fios condutores da primeira parte, no que concerne à dança, têm relação com esse diálogo/conflito ou ainda com a alternância entre o $2^{\circ}$ tema representado pelo solo, duos e trios de dançarinos e sua variação, à qual corresponde apenas duos. A fusão se processa pela estrutura, pelos temas e suas variações.

\section{Trios / Adagio (c. 66-81, marca de ensaio 6)}

A seção começa nos contrabaixos, com a reapresentação do $1^{\circ}$ tema (c. 8-10), de acordo com a análise de Marlene Fernandes (Fig. 8), variado por meio de modificações intervalares. Lembramos que esse tema ainda não havia sido explorado pela dança em sua primeira aparição. A terceira variação, nos contrabaixos, é imediatamente sucedida 
pelo violoncelo, em uma quarta variação, pelo procedimento de ampliação, com dois dançarinos e uma dançarina no palco, até a entrada de todos, antes do solo na flauta (c. $80)$.

\section{Figura 8: Erosão, $1^{\circ}$ Tema, c. 8-10, clarone e tuba.}

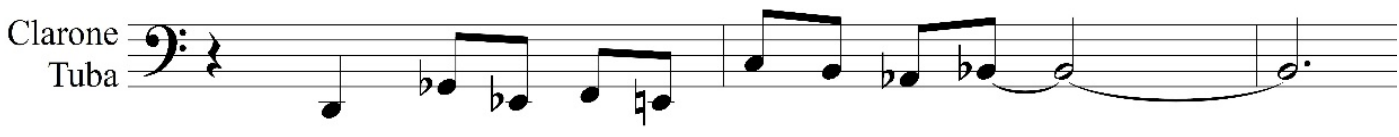

Fonte: VILLA-LOBOS, 1953, p. 19

Uma dançarina se destaca saindo do bloco, no lado esquerdo, dirigindo-se à frente do palco em diagonal, até o lado direito, onde estão penduradas faixas de tecido branco ilustrando a ideia de erosão. ${ }^{23}$ Temos aí uma relação de fusão, expressa pela textura: o solo de um instrumento corresponde ao solo de um dançarino. A dançarina solista realiza movimentos jazzy, com deslocamento dos quadris. sendo conduzida por dois dançarinos. ${ }^{24}$ "Deslocar o quadril para ter uma posição menos clássica. O quadril para frente", explica o coreógrafo. Essa parte musical lembra Ravel, Debussy e ainda Stravinsky, e, associado ao trio coreográfico, também o balé Agon (1958), "luta" em grego, obra característica do período americano do compositor russo. Do mesmo modo, Erosão, obra encomendada pela Orquestra de Louisville e estreada em 1950 nessa cidade no ano seguinte, sob a regência de Robert Whitney, marca o período americano de VillaLobos. A coreografia de Agon realizada por Georges Balanchine apresenta um jogo entre homens e mulheres em vários duos e trios num estilo neoclássico que se liberta dos preceitos clássicos. Agon e Erosão são ambas música de balé, contemporâneas e compostas nos Estados Unidos, que se libertam da tonalidade de maneira diferente e que se encontram aqui neste instante coreográfico de Erosão, que destaca a mulher e encontra certa ressonância nas variações de Agon. Além disso, a "sinuosidade ou mobilidade da coluna" como reformulação de preceitos clássicos, pensada pelo coreógrafo e que ilustram perfeitamente os movimentos da bailarina, é ampliada pela entrada de todos os dançarinos (c. 80), quando as meninas executam num plié os movimentos de 'quebra' da verticalidade da coluna com o topo do corpo, os braços e as costas.

\footnotetext{
${ }^{23}$ Colocamo-nos do ponto de vista do dançarino.

${ }^{24}$ Os dançarinos são a matéria do coreógrafo. A bailarina Priscila foi escolhida para fazer essa variação por sua corporalidade, ou seja, por ter um 'corpo jazz'.
} 


\section{Cubo / Piu Mosso (c. 86-143): 'Variação dos rapazes (elemento duro)'}

O cubo já evocado anteriormente corresponde em música à repetição de um esquema identificado por Marlene Migliari Fernandes como sendo um 'entrelaçamento do $2^{\circ}$ tema e $1^{\circ}$ tema' e tocado em diferentes alturas (c. 94-102). Na música, cada nota é acentuada, enquanto na dança se realiza uma acentuação nas mínimas para assim desenvolver "várias qualidades energéticas" (Bongiovanni). Uma transição, ou dissolução do esquema, (c. 134-143) corresponde à entrada das dançarinas e à saída dos dançarinos.

\section{Linha e Cubo / Meno (c. 144-173): Variação das mulheres (elemento líquido)}

Esta variação corresponde a uma transição, variações do $2^{\circ}$ tema, levada por uma dissolução, num pianíssimo. Seis dançarinas aparecem numa linha de frente ao público ao qual corresponde na música uma nota repetida nas cornetas, na primeira parte da transição (c. 144-154). Na segunda desta, (c. 154-164), outros instrumentos se juntam à pedal enquanto uma melodia inquietante, ascendente e descendente, nas cordas está sendo tocada. Depois, as bailarinas evoluem no palco na forma de cubo numa variação nas cordas do $2^{\circ}$ tema, (c. 165-167), que logo dá lugar a uma transição com pedal forte, (c. 167-173), enquanto bailarinos entram, para formar agrupamentos em duos com elas. Todos saem de cena quando inicia o solo do dançarino, demarcando a próxima seção.

\section{Solo 'e' / quase $A l^{\circ}$ (c. 174-226)}

Um dançarino executa um solo sobre uma nova variação do $2^{\circ}$ tema nos clarinetes (c. 177), antecipado pelos fagotes (c. 174-176, ensaio 18). Observamos também uma segunda voz nas cordas (c. 183), no ostinato do pandeiro. Esse solo se caracteriza por seu deslocamento rápido e por seus movimentos de qualidades opostas: expandir e contrair, recolher e ir para fora, resultado da reformulação de 'preceitos tradicionais' pensados a partir desse fenômeno de oposição da erosão. Caracteriza-se também pela linearidade nos ostinatos, que leva o dançarino a realizar movimentos de 'arrastar o chão', e por gestos angulosos ou geométricos; por exemplo, projetando seu cotovelo para cima para criar uma linha vertical e perpendicular ao chão. Nesse momento, as faixas brancas que estão penduradas em cima do palco são retiradas, reaparecendo apenas no final. 


\section{Mandala / A tempo (c. 227-277, ensaio 22)}

Os dançarinos se agrupam em forma de mandala, numa repetição do esquema anterior, nas cordas e nos sopros e num solo dos trompetes (c. 233-288), e começam a girar em sentidos opostos (c. 278), nas quintinas dos sopros. Esse trecho apresenta uma ampliação nesta repetição da variação do $2^{\circ}$ tema, com os sopros e cordas criando uma pausa que muda as relações entre os dançarinos (c. 243-244). Corresponde, com efeito, a um aumento espacial pelo olhar, com os dançarinos sendo orientados a expandir seus olhares para os outros e não apenas entre os três que formam os triângulos.

Uma dissolução com a presença do celesta, tam-tam, bombo, piano e harpa nos levam para ofinale (c. 277-288). Um intervalo joga o palco no escuro.

\section{Duos / Poco Lento e largo (c. 289-324, ensaio 28)}

Uma luz avermelhada invade o palco onde encontramos os dançarinos em duos, as dançarinas de costas para o público e empurrando os rapazes dos seus braços, com as mãos no torso destes. Empurram a erosão, tentam pará-la neste Poco Lento (c. 289-297), nesta transição, que vai crescendo do piano para o forte. Mais tarde, e de frente para o público desta vez, elas afastam as pernas para os lados segurando os rapazes pelo pescoço, de maneira sucessiva e a cada acorde tocado pelos pistons e sopros.

Figura 9: Duos. O elemento duro imobiliza o elemento fluído.

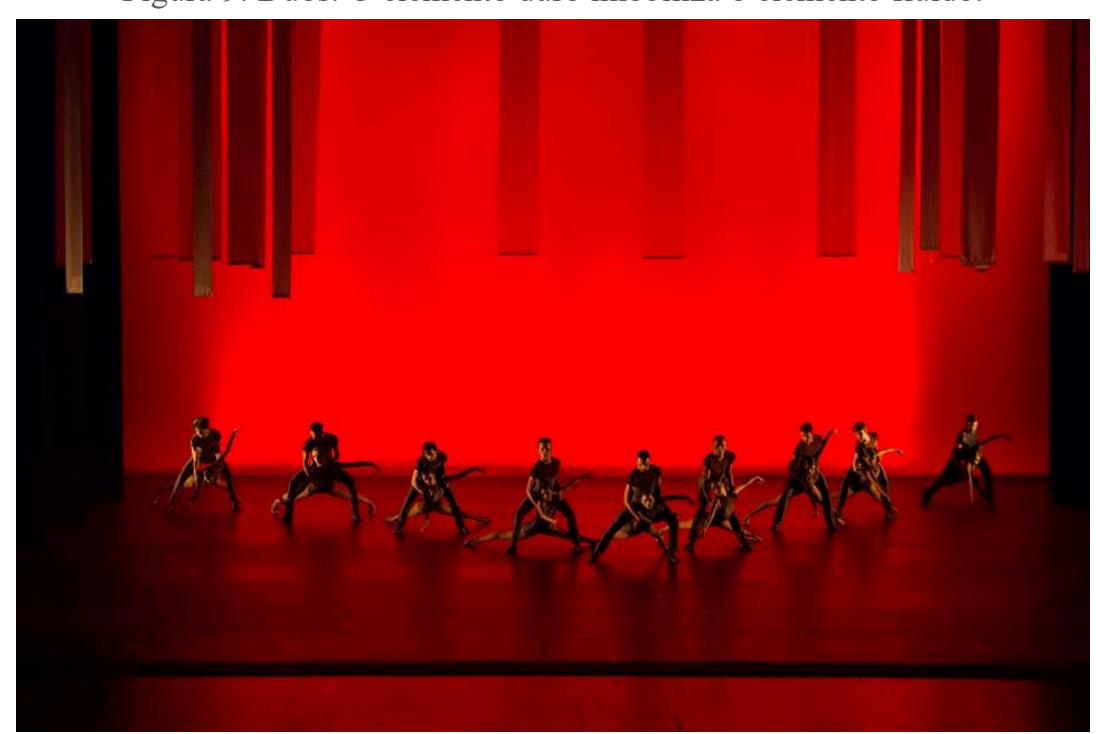

Fonte: Fotografia de Júlia Rónai, copyright (C) 2016, TMRJ. 
Marlene Migliari Fernandes vê neste finale uma reexposição dos temas derivados do $2^{\circ}$ tema (c. 298-309 e 325-326). No caso das cornetas e dos pistons, poderia tratar-se de um novo tema que corresponde na dança a numerosos portés onde se revelam a potência da natureza e suas forças opostas pela energia necessária para executar este tipo de figura coreográfica (c. 298 a 309). Em seguida, chega um momento de sossego introduzido pelo celesta, num tema para oboé (c. 314-324) que é uma "variação rítmica e timbrística" de um tema apresentado no início da obra (c. 55-65) (FERNANDES, 1999, p. 39), que pode ser interpretado como um momento possível de contemplação da transformação natural.

\section{Pas-de-deux / Grandeoso (c. 325-351, ensaio 31)}

Na retomada do novo tema por todos os instrumentos, inicia-se um pas-de-deux ao mesmo tempo que aparecem projetadas numa tela no fundo do palco as fotos da catástrofe de Mariana, absorvendo os dançarinos. A erosão aconteceu e esse novo tema final mostra o resultado. Num pedal e num pianíssimo (c. 337-fim), o rapaz impede que a mulher desenvolva seus movimentos, que vão se apagando aos poucos até ela se deitar no chão enquanto ele olha para o horizonte.

Ao focar na força da natureza e na sua destruição pelo homem, a obra respondeu à pergunta levantada pelo próprio coreógrafo Luiz Bongiovanni: qual é a relação entre o homem e a natureza? Essa interação do humano com a natureza lhe conferiu uma dimensão ecológica inerente à música de Villa-Lobos, que conseguiu justamente “incorporar [nela] um imponderável geofísico e humano" (DRUMMOND, 1959, p. 6). Assim, vimos, por exemplo, que o $2^{\circ}$ tema musical e sua variação, representando o sólido e o duro - sempre modificados por variações e assegurando a coerência do discurso musical -, colocam em movimento a erosão que a coreografia vem revelando no palco pela corporeidade e pelas roupas dos dançarinos, pela oposição entre o homem e a mulher e pelas figuras geométricas que traduzem as formações, deformações e reformações físicas resultantes da erosão. 


\section{Conclusões}

Nossa análise da obra demonstrou um novo uso de mitos e folclores indígenas no século XXI, que desloca a esfera nacional em direção ao universal, movimento que Mario de Andrade já evocava de alguma forma ao descrever a música Amazonas:

\footnotetext{
Essas forças sonoras são profundamente "natureza" e o pouco que retira da estética musical ameríndia não basta para localizá-la como música indígena. $\mathrm{E}$ mais que isso. Ou menos, se quiserem. Não é brasileiro também: é natureza (ANDRADE, 1930, p. 4).
}

Villa-Lobos era talvez o compositor mais adequado para representar o Brasil, em termos oficiais, nas Olimpíadas de 2016. É ele quem melhor representa a natureza - seus ruídos, ritmos e movimentos - em sua música.

A coreografia de Luiz Bongiovanni representou a primeira interpretação pela dança do poema sinfônico de Villa-Lobos. Como o demonstra nossa análise, o coreógrafo conseguiu traduzir a essência da música de Erosão. Sua coreografia é convincente e dá sentido à música ao revelar suas várias estruturas e formas pelo corpo dançante.

Podemos talvez, manifestar certa incompreensão a respeito das faixas brancas que aparecem de repente na obra e lamentar a projeção dos vídeos do 'Desastre da Mariana', pouco sutilmente dosada. No final da coreografia, com efeito, o casal de dançarinos, que usa roupas com cores similares àquelas apresentadas nos vídeos, se vê completamente engolido nos brilhos das projeções. A intenção coreográfica, descrita no fim de nossa análise, era, porém, suficiente para entender a tragédia e os vídeos resultaram em uma ênfase desnecessária. Talvez teria sido mais judicioso introduzir esse segundo balé da trilogia por meio desta projeção de imagens, enfatizando então, nessa mesma ocasião, como as artes testemunham e interpretam a realidade.

Além disso, o contexto de criação da Trilogia Amazônica foi marcado por problemas políticos e econômicos sob a presidência de Dilma Rousseff. A companhia sofreu com uma diminuição de ensaios e algumas apresentações da Trilogia Amazônica foram canceladas. Logo depois, em fevereiro de 2017, o presidente do Theatro Municipal do Rio de Janeiro, João Guilherme Ripper, foi demitido e a obra que deveria ser apresentada novamente, um ano depois de sua criação - ou seja, em 2017 -, com modificações necessárias e normais destinadas a melhorar a qualidade do conjunto, no 
que tange à interpretação musical e coreográfica ou ainda aos figurinos e desenhos, foi esquecida. E além de não ter sido apresentada depois, sequer foi gravada na sua totalidade durante as apresentações no Theatro Municipal do Rio de Janeiro.

\section{Referências}

ANDRADE, Mario de. Amazonas de Villa-Lobos. Diário Nacional. São Paulo, 26 set. 1930, coluna Sociedade Sinfônica de São Paulo, p. 4.

APPLEBY, David. The Villa-Lobos Letters (Musicians in Letters). Londres: Toccata Press, 1994.

AZEVEDO, Luiz Heitor Corrêa de. 150 anos de Música no Brasil (1800-1950) / Luiz Heitor; prefacio: Ricardo Tacuchian. 2 ed. Rio de Janeiro: FBN, Coordenadoria de Editoração, 2016.

BEAUFILS, Marcel. Musicien et poète du Brésil. Paris: IHEAL [Institut des hautes études de l’Amérique latine], 1988.

BEHAGUE, Gérard. Heitor Villa-Lobos: the search for Brazil's musical soul. University of Texas, Austin: Institute of Latin of American Studies, 1994.

BRITO CHAVES, Edgard. Memórias e glórias de um teatro sessenta anos de história do Teatro Municipal do Rio de Janeiro. Rio de Janeiro: Companhia Editora Americana 1971.

CARLONI, Karla Guilherme. Em busca da identidade nacional: bailarinas dançam maracatu, samba, macumba e frevo nos palcos do Rio de Janeiro (1930-1945). ArtCultura, Uberlândia, v. 16, n. 29, jul.-dez. 2014, p. 167-185.

CORSEUIL, Jacques. Ballet no Conselho Nacional da Cultura. Correio da Manhã, Rio de Janeiro, 3 set. $1961.1^{\circ}$ Caderno, p. 6.

DRUMMOND ANDRADE, Carlos. Glória amanhecendo. Correio da Manhã, Rio de Janeiro, 19 nov. $1959,3^{\circ}$ Caderno, p. 3.

FERNANDES, Marlene Migliari. Processos de estruturação em Villa-Lobos Erosão. [S.1.: s.n.]. 1999.

GRIECO, Donatello. Roteiro de Villa-Lobos. Brasília: Fundação Alexandre de Gusmão, 2009. Disponível em: http://funag.gov.br/loja/download/620-Roteiro_de_Villa-Lobos.pdf. Acesso em: 27/08/2020.

HARRIS-WARRICK, Rebecca et al. Ballet. In: Grove Music Online. 2001. Disponível em: https://doi.org/10.1093/gmo/9781561592630.article.46700. Consultado em 09/12/2020.

KIEFER, Bruno. Villa-Lobos e o Modernismo na Música Brasileira. Porto Alegre: Editora Movimento, 1981.

LAGO, Manoel Aranha Corrêa do. Villa-Lobos e o balé do século XX. Theatro Municipal do Rio de Janeiro. Trilogia Amazônica, Temporada de Ballet 2016. 
LATERZA FILHO, Moacyr. Erosão, "a origem do rio Amazonas". [s.d.]. Disponível em: http://www.filarmonica.art.br/educacional/obras-e-compositores/obra/erosao-origemrio-amazonas-1950/. Acesso em: 12/02/2020.

MARIZ, Vasco. Heitor Villa-Lobos. 11 ed. Belo Horizonte: Itatiaia, 1989.

MCDONALD, Hugh. Symphonic poem (Ger. symphonische Dichtung; Fr. poème symphonique). In: Grove Music Online. 2001. Disponível em: https://doi.org/10.1093/gmo/9781561592630.article.27250. Consultado em 09/12/2020.

MINISTÉRIO PÚBLICO FEDERAL. Caso Samarco. "O Desastre". Disponível em: http://www.mpf.mp.br/grandes-casos/caso-samarco/o-desastre. Acesso em 30 jul. 2020.

MURICY, Andrade. Villa-Lobos uma interpretação. Rio de Janeiro: Museu Villa-Lobos/MEC, 1960.

PEPPERCORN, Lisa. Heitor Villa-Lobos: leben und werk des brasilanischen komponisten. Zürich und Feiburg: Atlantis Verlag, 1972.

PEREIRA, Roberto. A formação do balé brasileiro: nacionalismo e estilização. Rio de Janeiro: FGV, 2003.

RODRIGUES, João Barbosa. 1890. "Sorimáo U Ypirungaua, A origem do Rio Solimões". Poranduba amazonense, ou kochiyma-uaraporandub, 1872-1887. Rio de Janeiro: Typ. de G. Leuzinger \& Filhos. Disponível em: http://biblio.etnolinguistica.org/rodrigues_1890_poranduba. Consultado em 09/12/2020.

SALLES, Paulo de Tarso. Villa-Lobos: processos composicionais. Campinas, SP: Editora da Unicamp, 2009.

VILLA-LOBOS, Heitor. Erosão. Paris: Max Eschig, c.1955.

THEATRO MUNICIPAL DO RIO DE JANEIRO. Trilogia Amazônica, Temporada de Ballet 2016. Programa do espetáculo. 


\section{Anexo 1}

\section{FICHA TÉCNICA}

Erosão, a origem do Rio Amazonas (1950)

Parte II da Trilogia Amazônica

2016

Apresentações

03, 04, 06, 11, 12 e 13 de agosto | 20h

07 e 14 de agosto | $17 \mathrm{~h}$

Coreografia

Luiz Fernando Bongiovanni

Música

Heitor Villa-Lobos

Assistente de coreografia

Nina Botkay

Ensaiador

Manoel Francisco

Cenografia

Gringo Cardia

Figurino

Renê Salazar

Iluminação

Maneco Quinderé

Diretoras artísticas do BTM

Ana Botafogo e Cecília Kerche

Ballet e Orquestra Sinfônica do Theatro Municipal do Rio de Janeiro

$$
\begin{gathered}
\text { Regência } \\
\text { Tobias Volkmann } \\
\text { Presidente } \\
\text { João Guilherme Ripper }
\end{gathered}
$$

Fundação Teatro Municipal do Rio de Janeiro

\section{Diretor Artístico \\ André Cardoso}

Fundação Teatro Municipal do Rio de Janeiro

\section{Elenco}

Solistas: Karen Mesquita, Priscila Albuquerque, Viviane Barreto,

Filipe Moreira, Murilo Gabriel, Rodrigo Negri, Luan Batista Moças: Carolina Neves, Mônica Barbosa, Paula Damiane,

Priscilla Mota, Renata Gouveia, Samantha Monteiro, Thaís Danello, Aimé Rodriguez

Rapazes: Anderson Dionísio, Arthur Sai, Edifranc Alves, 